\title{
Bird diversity of tea plantations in Darjeeling Hills, Eastern Himalaya, India
}

\author{
ABHISHEK CHETTRI, KISHOR SHARMA, SAILENDRA DEWAN, BHOJ KUMAR ACHARYA \\ Department of Zoology, School of Life Sciences, Sikkim University, Tadong, Gangtok-737102, Sikkim, India \\ Tel.: +91-3592-231302, "email: bkacharya@cus.ac.in
}

Manuscript received: 31 March 2018. Revision accepted: 15 May 2018.

\begin{abstract}
Chettri A, Sharma K, Dewan S, Acharya BK. 2018. Bird diversity of tea plantations in Darjeeling Hills, Eastern Himalaya, India. Biodiversitas 19: 1066-1073. The biodiversity wealth and conservation potential of agro-ecosystems including cash crop plantations is gaining significance in recent years. Agro-forestry provides ecosystem services similar to forest and, hence, support a high diversity of flora and fauna. This study was undertaken to explore the bird community in different tea gardens of Kurseong Hill, Darjeeling, Eastern Himalaya, India. Darjeeling is globally known for its extent and magnificent tea production. We sampled birds using point count methods along transects during August 2015-January 2016. A total of 581 individual birds comprising 48 species were recorded during the study. Amongst the guild types, insectivorous birds were the most dominant both in terms of species and abundances. Depending on their habitat preferences most of the birds were forest generalists followed by forest specialists. This study highlights that tea plantations have a great potential in harbouring and conserving birds and other associated life forms. Thus, proper management of these landscapes would be an effective strategy to conserve biodiversity of the Himalayas.
\end{abstract}

Keywords: Agroecosystems, birds, conservation, Himalaya, Kurseong, tea plantation

\section{INTRODUCTION}

Tropical landscapes are dominated by various land-use systems including diverse production agroforestry systems (Tscharntke et al. 2008). Among such systems, agroecosystems which are primarily meant for production of crops, if managed organically, traditionally or maintained with diverse shade trees can conserve significant amount of wild biodiversity with unique community assemblages of plants and animals (Mayfield et al. 2005; Mcneely and Schroth 2006; Barlow et al. 2007; Harvey and Villalobos 2007; Vandermeer and Perfecto 2007; Lin et al. 2012; Sreekar et al. 2013; Sharma and Vetaas 2015; Mellink et al. 2017). While most of the agro-ecosystems are managed using traditional ecological knowledge, many are substantially modified using recent technology to meet food, fibre and other livelihood requirements of the everincreasing human population (Laurance et al. 2014). Achieving conservation goals within such humandominated landscapes, however, requires detailed understanding of the functioning of different agricultural ecosystems, their appropriate management, and potentiality of these systems to conserve flora and fauna (Flohre et al. 2011).

A number of studies have focused on biodiversity in shaded agroforestry systems using birds as an indicator and highlighted their importance in conserving the habitat of various organism including birds (Thiollay 1995; Uezu et al. 2008; Elsen et al. 2016). The impact of site-scale forest disturbance on organisms depend on the extent of forest cover within the surrounding landscape (Dahal et al. 2015) because species commonly interact with the agro- ecosystems even if their primary habitat is the natural forests (Pimentel et al. 1992).

The tea plantation is one of the important agroecosystems and contributes largely to a country's economy. Since most tea plantations strictly follow monoculture practices, biodiversity assemblages in such plantations are poor compared to forest ecosystems (Lin et al. 2012; Ahmed and Dey 2014) and other agroforestry ecosystems, such as pine plantations (Soh et al. 2006), home gardens (Yashmita-Ulman et al. 2016) but richer than Eucalyptus plantation monocultures (Kottawa-Arachchi and Gamage 2015) and agrosiliviculture systems (Yashmita-Ulman et al. 2016). Among the tea plantations, shade tea cultivation (tea cultivation with diverse shade trees) and surrounding forest patches has a high capacity to maintain biodiversity within itself (Lin et al. 2012; Sreekar et al. 2013; Ahmed and Dey 2014) than monoculture tea plantations (Soh et al. 2006) or abandoned tea plantations (Subasinghe and Sumanapala 2014) because shade trees provide habitat for both forest and open land birds and also acts as a buffer zone and feeding ground for the frugivorous and insectivorous species (Bhagwat et al. 2008; Sinu 2011). In some cases, the bird diversity in the shade tea plantations is comparable to the surrounding forest ecosystems (Ahmad and Yahya 2010; Sreekar et al. 2013). The natural windbreaks of native tree in tea dominated landscapes of Western Ghats enhanced bird diversity as they retain significant proportion of the resident birds found in the forests (Sreekar et al. 2013). Some studies have even reported that tea plantations are rich in birds including endemic, rare or IUCN Red List threatened species (Sreekar et al. 2013; Kottawa-Arachchi and Gamage 2015; Yashmita-Ulman et al. 2016). While 
these ecosystems form the important habitats for various animal groups, exploration of biological wealth and recognition of significance of such systems as habitat is not given due consideration (Ahmed and Dey 2014).

The Eastern Himalayan region comprises diversity of agro-forestry systems and is considered as important land use practices (Sharma et al. 2007). Darjeeling is a northeastern district of West Bengal state in India and is one of the largest producers of tea in the world. The world-famous tea garden of Darjeeling hills represents one of the most important landuse systems in the Eastern Himalaya with mosaic of tea bushes, agricultural areas, and forest patches. The history of tea plantation in Darjeeling dates back to 1841, and from 1971 onwards the process of organic farming began by transforming tea plantation into an integrated, sustainable ecosystem (Datta 2010). While few studies have been undertaken to understand the conservation potential and community structure of birds in tea plantation in this region but are mostly explorative (Ahmad and Yahya 2010; Ahmed and Dey 2014). Ahmad and Yahya (2010) recorded a total of 130 species of birds in six different habitat types of Kurseong Hill out of which
48 species were encountered at the productive tea plantation. The present study explored different tea cultivation sites to understand the community structure, guild composition and habitat specialization of birds within the mosaic of agro-forestry systems covering four tea gardens in Kurseong Hill located in Darjeeling District, West Bengal, India-a globally significant but human modified landscape in the Eastern Himalaya.

\section{MATERIALS AND METHODS}

\section{Study area}

This study was undertaken in the various tea gardens of Kurseong Hill located in the Darjeeling District of West Bengal State in India (Figure 1, Table 1). All the tea gardens sampled in the present study are located in Kurseong block which has an area of $342.6 \mathrm{~km}^{2}$, situated within Kurseong sub-division of Darjeeling District. The study sites were located at a distance of 1.5 to $3 \mathrm{~km}$ from each other with extent of the gardens ranging from 34.5 to 610 ha (Table 1).

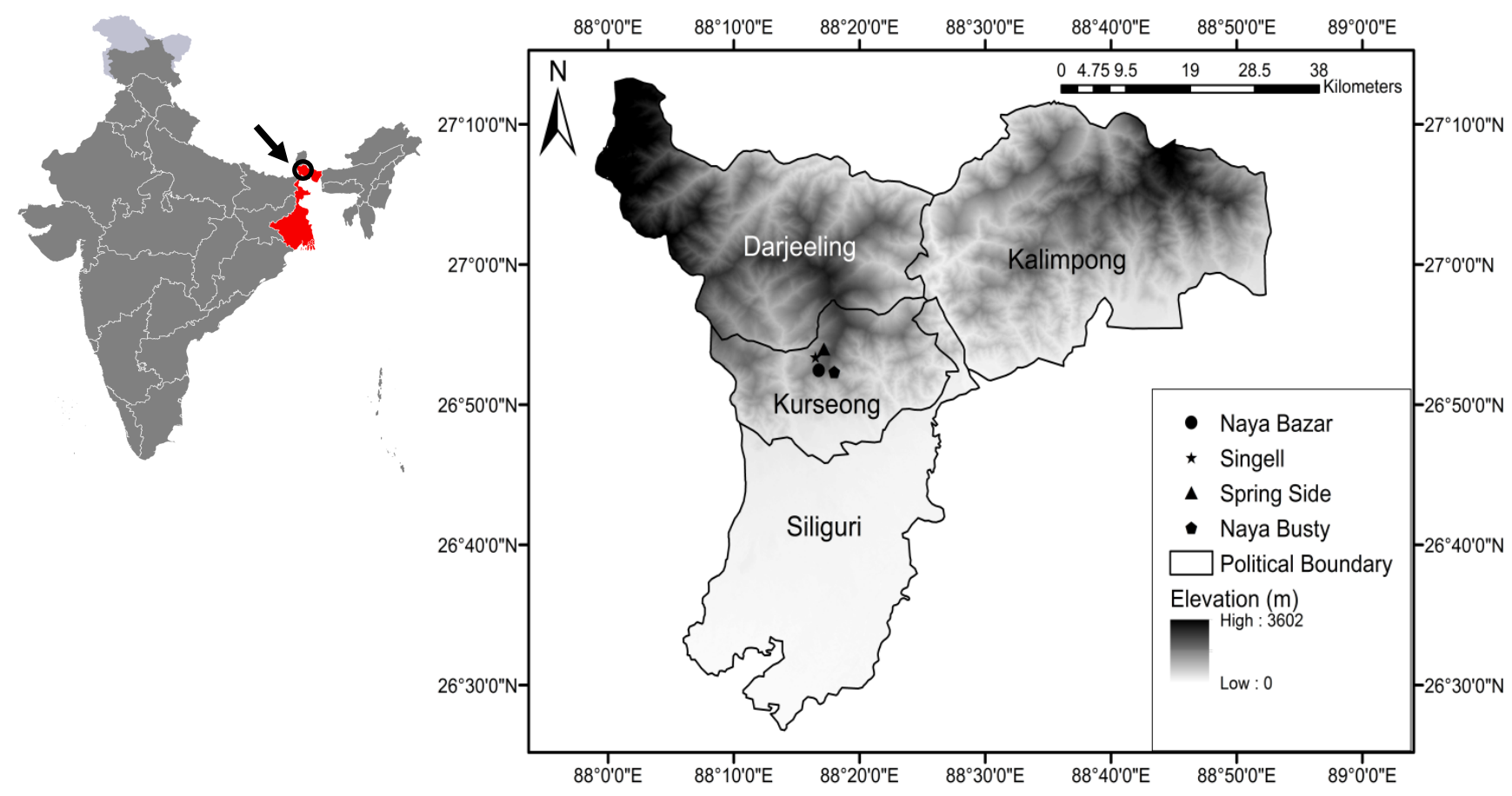

Figure 1. Map of the study area showing sampling sites in Kurseong Hill, Darjeeling, West Bengal, Eastern Himalaya, India

Table 1. Details of bird sampling sites located in Kurseong Hill, Darjeeling, Eastern Himalaya, India

\begin{tabular}{lllll}
\hline Study site & Elevation $(\mathbf{m})$ & Latitude & Longitude & Extent/area (ha) \\
\hline Singell & 1372 & $26^{0} 53.383^{\prime} \mathrm{N}$ & $88^{0} 16.496^{\prime} \mathrm{E}$ & 610 \\
Spring side & 1406 & $26^{0} 53.963^{\prime} \mathrm{N}$ & $88^{0} 17.1411^{\prime} \mathrm{E}$ & 144.184 \\
Naya Bazar & 1533 & $26^{0} 52.443^{\prime} \mathrm{N}$ & $88^{0} 16.755^{\prime} \mathrm{E}$ & 170 \\
Naya Busty & 1598 & $26^{0} 52.430^{\prime} \mathrm{N}$ & $88^{0} 17.936^{\prime} \mathrm{E}$ & 34.5 \\
\hline
\end{tabular}


The tea plantations in Darjeeling hills is unique as it has numerous important characteristic features of its own (Datta 2010). Kurseong, the land of white orchid, is a small hill station situated at an elevation of $1490 \mathrm{~m}$ above mean sea level. The study was conducted in four tea estates in Kurseong (Table.1). All the four tea gardens are organically managed. The topography comprises moderate slopes, with moderately permeable and reasonably welldrained soil. The plantation comprises tea shrubs (Camelia sinensis var. sinensis) which reaches a height of about 0.5 $1 \mathrm{~m}$. Shade trees that occur along with tea bushes are Schima wallichii, Cryptomeria japonica, Albizia procera, Alnus nepalensis, Syzygium nervosum, Exbucklandia populnea, Eurya japonica, Ficus religiosa, Ficus benghalensis and mixed bamboo groves. The tea gardens are characterized by several habitats such as home-garden, forest patches, wetlands in the form of streams and open grasslands making it ideal for variety of organism to thrive within its vicinity (Ahmed and Dey 2014; Ahmad and Yahya 2010). Six different habitat types (mixed bamboo, riverine, tea plantation, dense forest, edge, and scrub) are reported to be found in Makaibari tea estate of Kurseong Hill (Ahmad and Yahya 2010). However, in the absence of good forest patch in all the four different tea gardens in the present study, we focused only on the tea plantations as a study habitat.

\section{Data collection}

Variable width point count method along transect was used for sampling birds (Bibby et al. 2000). Transects were laid along tea plantations only. Point count method is an effective census technique because the stationary observer has a greater probability of detecting and hearing birds even if the birds are inside the bushes. This method was adopted keeping in view the hilly terrain and rough topography of the study area (Acharya et al. 2011; Acharya and Vijayan 2017). In each site mentioned in the study area above, four transects were established, and within transect five points were marked making a total of 20 points per site. The points within transects were spaced $100 \mathrm{~m}$ apart in order to avoid repetitive counting of same individuals during sampling. Hence, a total of 80 points were laid for the present study covering four study sites. In each point observation of birds were made for 10 minutes recording the number and identity of species seen or heard. Birds were scanned with the help of a binocular and identified using the standard field guide (Grimmett et al. 2011). Sampling was conducted in the morning hours (06:0010:00 hrs) in clear sunny days during August 2015 to January 2016. Bird counts were repeated three times in each transect.

\section{Data analysis}

Various community parameters such as species richness, abundance, species per point, abundance per point and diversity indices were calculated for birds of the study area. Species richness is the cumulative list of species observed during the sampling. Similarly, abundance is the total number of individuals counted during the sampling. Shannon-Weiner index $\left(\mathrm{H}^{\prime}\right)$ is calculated as $\mathrm{H}^{\prime}=-\sum$ pilnpi, where pi is the proportion of individuals of the $i^{\text {th }}$ species in the community and $l n$ is the natural logarithm. Evenness (E) is computed as $\mathrm{E}=\mathrm{H}^{\prime} / \mathrm{H}_{\max }=\mathrm{H}^{\prime} / \ln \mathrm{S}$ where $\mathrm{S}$ is the species richness. Species richness is the basic indicator considered during implementation of conservation measures, but there is a possibility of missing some species during sampling resulting into underestimation of real number of species present in the area or habitat. Hence, different non-parametric richness estimators were computed using the software EstimateS version 9.0.1 (Colwell 2014). Among the various non-parametric estimators, we selected Chaol because it detects rare species and is widely used. To test whether the sampling effort was enough to detect all the species that occur in the study area species accumulation curve was produced, based on the observed and non-parametric estimator Chaol, by plotting the cumulative number of species detected against the sampling effort.

Feeding guild and habitat specialization of the birds were assigned according to their autecological traits following Sreekar et al. (2013) and Grimmett et al. (2011). We computed relative percentages of birds (both species richness and abundance) in each category (feeding guild and habitat specialization). Bird taxonomy follows Praveen et al. (2018).

\section{RESULTS AND DISCUSSION}

\section{Species richness, diversity, and abundance}

During this study, a total of 581 individual birds representing 48 species and 28 families were observed from four study sites in the tea garden of Kurseong Hill, Darjeeling, Eastern Himalaya (Table 2, Table S1). Shannon-Weiner diversity for birds was 3.2. Species richness per point was $3.3 \pm 1.1$ and abundance per point was $7.3 \pm 3.3$. Similarly, Evenness was 0.83 indicating that the species were fairly evenly distributed in the community. The different bird community parameters differed among the four tea gardens (Table 2). The diversity and species richness of birds observed in the present study are greater than (Soh et al. 2006; Lin et al. 2012; Sreekar et al. 2013; Subasinghe and Sumanapala 2014), comparable to (Ahmad and Yahya 2010; Ahmed and Dey 2014) or lesser than (Kottawa-Arachchi et al. 2010; Yashmita-Ulman et al. 2016) studies undertaken in tea plantations in India and elsewhere. Such differences could be due to variation in climatic conditions, elevation, area covered, shade trees, disturbance factors and proximity to primary forest.

The species accumulation curve based on observed and the non-parametric estimators of species richness almost reached an asymptote indicating likelihood of encountering few more species with increasing sampling effort (Figure 2). 
Table 2. Species richness, abundance, diversity, evenness and non-parametric species richness estimators of bird communities in the four tea gardens of Kurseong Hill, Darjeeling, Eastern Himalaya, India

\begin{tabular}{llllll}
\hline \multirow{2}{*}{ Community parameters } & \multicolumn{4}{c}{ Study site (tea gardens) } & Total \\
\cline { 2 - 5 } & Singell & Spring Side & Naya Bazar & Naya Busty & 48 \\
\hline Species richness & 28 & 29 & 28 & 21 & $3.3 \pm 1.1$ \\
Species per point $($ Mean \pm SD) & $3.3 \pm 1.2$ & $3.4 \pm 1.1$ & $3.05 \pm 1.05$ & $3.1 \pm 0.8$ & 581 \\
Abundance & 139 & 159 & 131 & 152 & $7.3 \pm 3.3$ \\
Abundance per point $($ Mean \pm SD) & $7.0 \pm 3.0$ & $7.7 \pm 4.0$ & $6.5 \pm 2.7$ & $2.8 \pm 3.4$ & 3.2 \\
Shannon-Weiner index & 3.01 & 2.89 & 2.89 & 2.61 & 0.83 \\
Evenness & 0.91 & 0.86 & 0.86 & 0.85 & $48 \pm 2.56$ \\
S (Est.) (mean \pm SD) & $28 \pm 2.28$ & $29 \pm 3.73$ & $28 \pm 3.14$ & $21 \pm 2.17$ & $51.59 \pm 3.85$ \\
Chao 1 (mean \pm SD) & $29.32 \pm 1.83$ & $37.11 \pm 8.22$ & $30.55 \pm 2.79$ & $21.28 \pm 0.67$ & \\
\hline
\end{tabular}

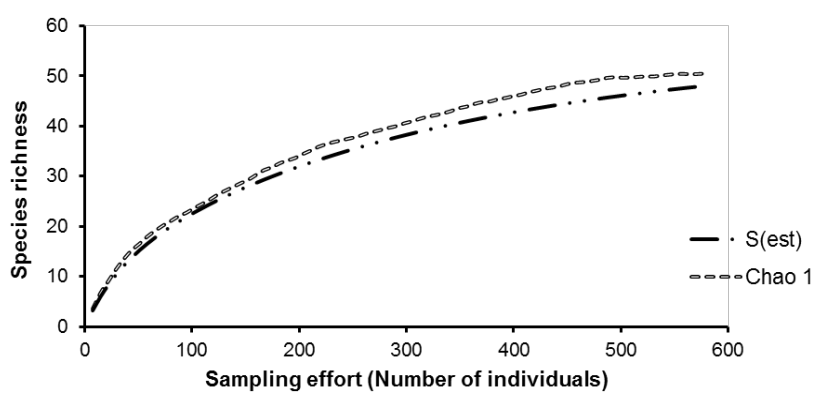

Figure 2. The species accumulation curves based on observed and estimated species of birds of tea garden of Kurseong Hill, Darjeeling, Eastern Himalaya, India

The non-parametric estimators Chaol predicted 50 species which was $95.05 \%$ of the observed species richness (48 species). Out of the total 581 individual birds counted during the sampling, the three most dominant species (Olive-backed Pipit Anthus hodgsoni, Red-vented Bulbul Pycnonotus cafer, and Grey Bushchat Saxicola ferreus) contributed $34.6 \%$ of the total abundance.

\section{Feeding guilds}

The observed birds of the tea gardens were categorized into six feeding guilds namely, insectivore, omnivore, carnivore, frugivore, nectarivore and granivore. As expected, the bird community was highly dominated by the insectivores, both in terms of species richness ( 35 species; $72.92 \%)$ and abundance (88.81\%) (Figure 3). The other five feeding guilds were not well represented in the bird community.

\section{Habitat specialization}

The birds observed in the present study belonged to three groups according to their habitat specialization namely, forest specialist, forest generalist, and open-land. The forest generalist birds were the most dominant group both in terms of species richness (33 species; 68.75\%) and abundance $(62.13 \%)$ contributing about two-third to the bird community. The second most dominant group was forest specialist but contributed only about one-fifth to the bird community (Figure 4).

Ahmad and Yahya (2010) recorded a total of 130 species of birds in six different habitat types (mixed bamboo, riverine, tea plantation, dense forest, edge, and scrub) of Kurseong Hill out of which 48 species were found in the productive tea plantation. The bird species richness observed in the present study was similar to the species found in tea plantations (48 vs. 48 species), and $37 \%$ of the birds reported to occur in different habitat types (48 vs. 130 species) of Kurseong Hill (Ahmad and Yahya 2010). During the present study, we observed 20 additional bird species not recorded by Ahmad and Yahya (2010), which makes up the total bird species of tea plantation of Kurseong Hill to 68 and total bird species of different habitats of Kurseong Hill to 150 species. Since tea plantation is the most dominant land uses in Darjeeling, the result indicates great potential of this agro-ecosystem in supporting and conserving avifaunal diversity. The nonparametric estimators estimated 50 species that might occur in the study area which is closer to the observation of Ahmad and Yahya (2010) and the present study. High bird diversity could be attributed to the presence of shade trees along with tea bushes providing habitats for various activities of birds. Studies have found strong correlation between bird community and habitat diversity suggesting the dependency of birds on the compositional complexity of trees, shrubs and herbs in both forest ecosystems (Acharya et al. 2011; Chettri et al. 2005; Chettri 2010; MacArthur et al. 1966) and tea plantations (Sreekar et al. 2013; Yashmita-Ulman et al. 2016). The potential factors affecting bird communities in tea plantation are patch size (Yashmita-Ulman et al. 2016), tree species richness and diversity (Sreekar et al. 2013; Yashmita-Ulman et al. 2016) and arthropod abundance (Sinu 2011).

The bird community in the present study was highly dominated by insectivores both in terms of species richness and abundance. Higher dominance of insectivorous species is a commonly observed phenomenon, both in tea plantations (Ahmad and Yahya 2010; Kottawa-Arachchi et al 2010; Sreekar et al. 2013; Ahmed and Dey 2014; Yashmita-Ulman et al. 2016) and other human-modified and forest ecosystems (Chettri et al. 2005; Chettri 2010; Bhatt and Joshi 2011; Sreekar et al. 2013). The present study system represents organic farming in which use of chemical fertilizers is prohibited, and insect abundances could be high favoring the occurrences of more number of insectivorous birds. These birds might play crucial role as a biocontrol agent in organically managed tea gardens and other farming ecosystems (Sinu 2011). 


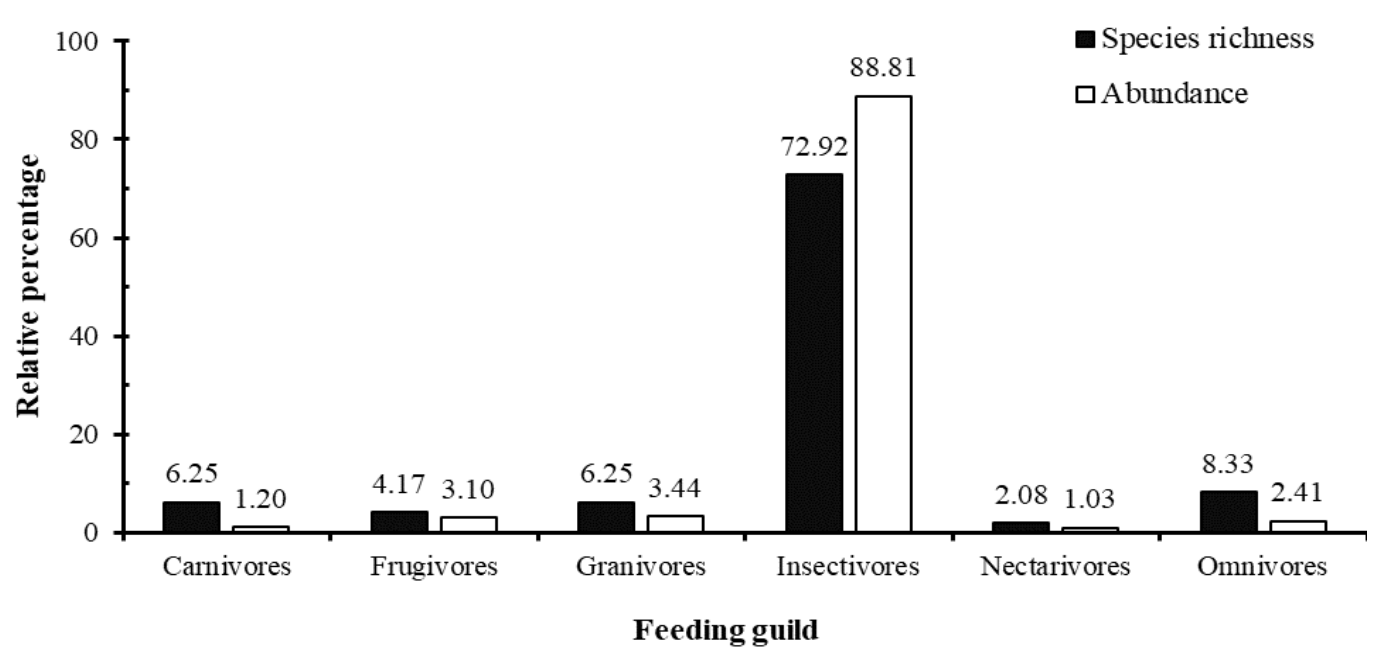

Figure 3. Proportion of birds according to their feeding guild observed in tea gardens of Kurseong Hill, Darjeeling, Eastern Himalaya, India

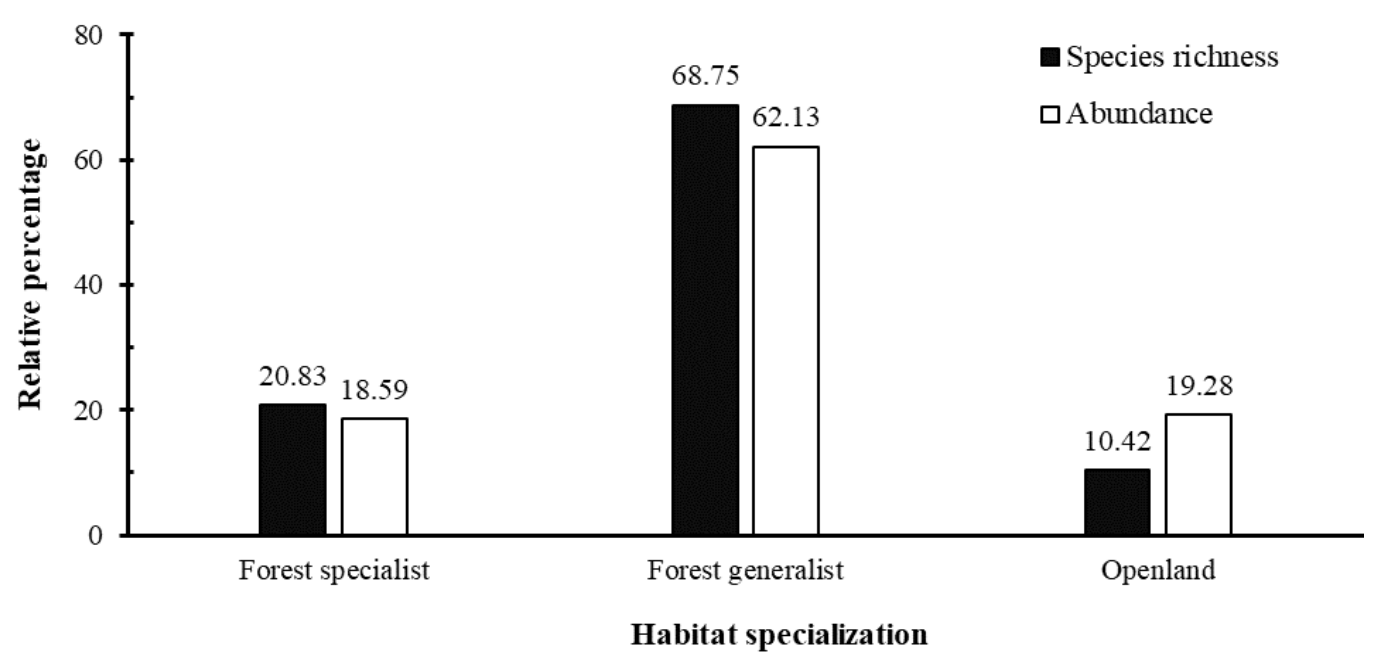

Figure 4. Proportion of birds according to their habitat specialization (forest specialist, forest generalist, and open-land) observed in tea gardens of Kurseong Hill, Darjeeling, Eastern Himalaya, India

The tea plantation in India has been reported to harbor and get infested by more than 300 species of phytophagous insects and mites (Hazarika et al. 2009). The high load of pest in the tea plantations are generally controlled by widespread and regular use of pesticides. The bio-control of this wide range of insect pests has been proposed through arthropod natural enemies namely, predators and parasitoids (Das et al. 2010) and also by insectivorous birds (Sinu 2011). High diversity of arthropod natural enemies (94 species of predators and 33 species of parasitoids) has been reported in sub-Himalayan tea plantations of North Bengal (Das et al. 2010). Sinu (2011) reported the biocontrol role played by birds in tea plantations of Northeast India against the invasive geometrid looper caterpillars (Hyposidra spp.) and lymantriid hairy caterpillar (Arctornis submarginata). These caterpillars caused large-scale defoliation of tea leaves but had no resident insect predator for any of their life stage.

In the present study, forest generalist birds were the most dominant group both in terms of species richness and abundance contributing about two-third of the bird community. In Argentina, most of the productive landscapes were dominated by forest generalists while the forest specialists were mostly confined to rain forests (Mastrangelo and Gavin 2014). Old-growth forest cover showed the strongest association with the diversity of forest specialist species in fragmented Lacandona rain forest (Carrara et al. 2015). Low occurrence of forest specialists in the tea gardens might be because of its vulnerability to changing landscapes. Traditional agro-forests, with a 
mixture of cultivated and natural shade trees, can support a high number of species including many forest birds, especially in areas that are close proximity to natural forests (Greenberg 1981). Forest specialist bird species are also reported to use agro-ecosystems for different activities (Pimentel et al. 1992). Hence, shade tea plantations and other human-modified ecosystems such as home gardens, agrisilviculture, etc. may act as corridors between forest patches that occur in the proximity of such fragmented landscapes (Kottawa-Arachchi et al. 2010; Sreekar et al. 2013).

\section{Conservation implications}

We recorded 48 bird species from our study in tea plantations of Kurseong in Darjeeling hills, Eastern Himalaya. This short-term study highlighted that the organically managed tea plantations have great potential in harboring and conserving bird diversity. We did not record any endemic, or IUCN Red List threatened species in the present study. However, four species observed in the present study are listed in CITES Appendix II (Asian Barred owlet Glaucidium cuculoides, Common Kestrel Falco tinnunculus, Eurasian Sparrowhawk Accipiter nisus, Red-billed Leiothrix Leiothrix lutea) (CITES 2018). Eleven species can be considered as rare because five species were represented by two individuals and six species had single individuals. Presence of shade trees in tea gardens is of great importance as they improve connectivity with the forests and ensure suitable habitat for birds and other wild animals. Hence, the future of the Himalayan biodiversity depends more on the effective management of humanmodified landscapes presenting a daunting challenge to the conservation practitioners and land-use managers in order to conserve avian and other floral and faunal diversity of this region. Being organically managed (in the absence of pest control by insecticides and pesticides) the role of natural pest predators and parasitoids in addition to insectivorous birds in control of tea pests becomes crucial. Therefore, a long-term extensive study covering different tea estates is necessary to understand the biodiversity conservation potential of tea plantations in the region. The roles of birds as a bio-control agent of tea pests must be addressed through long-term extensive study covering different tea estates and natural ecosystems.

\section{ACKNOWLEDGEMENTS}

This paper is an outcome of the M.Sc. thesis of the first author. We thank Vice Chancellor, Dean (School of Life Sciences) and Head (Department of Zoology) of the Sikkim University (SU), India for providing facilities to undertake this research. We also thank all the faculty members of Zoology Department, SU for various support and cooperation. The support of local community of tea gardens of Kurseong Hill, while undertaking fieldwork, is highly appreciated. KS was supported by Junior Research Fellowship from University Grants Commission, New Delhi during the manuscript preparation.

\section{REFERENCES}

Acharya BK, Sanders N, Chettri B, Vijayan L. 2011. Elevational gradients in bird diversity in the Eastern Himalaya: an evaluation of distribution patterns and their underlying mechanisms. PLoS One 6: e29097. DOI: 10.1371/journal.pone.0029097.

Acharya BK, Vijayan L. 2017. Vertical stratification of birds in different vegetation types along the elevation gradient in the Eastern Himalaya, India. Ornithological Science 16 (2): 131-140.

Ahmad K, Yahya HAS. 2010. Winter diversity of birds in Makaibari Tea Estate, Kurseong, Darjeeling, India. Indian Forester 139 (10): 69-87

Ahmed A, Dey M. 2014. A checklist of winter birds community in different habitat types of Rosekandy tea estate of Assam, India. J Threat Taxa 6 (2): 5478-5484.

Barlow J, Mestre LAM, Gardner TA, Peres CA. 2007. The value of primary, secondary and plantation forests for Amazonian birds. Biol Conserv 136 (2): 212-231.

Bhagwat SA, Willis KJ, Birks HJB, Whittaker RJ. 2008. Agroforestry: a refuge for tropical biodiversity? Trends Ecol Evol 23 (5): 261-267.

Bhatt D, Joshi KK. 2011. Bird assemblages in natural and urbanized habitats along elevational gradient in Nainital district (western Himalaya) of Uttarakhand state, India. Curr Zool 57 (3): 318-329.

Bibby CJ, Burgess ND, Hill DA, Mustoe SH. 2000. Bird Census Technique. Academic Press, London.

Carrara E, Arroyo-Rodriguez V, Vega-Riviera JH, Schondube JE, de Freitas SM, Fahrig L. 2015. Impact of landscape composition and configuration on forest specialist and generalist bird species in the fragmented Lacandona rainforest, Mexico. Biol Conserv 184: 117126.

Chettri N, Deb DC, Sharma E, Jackson R. 2005. Relationship between bird communities and habitat: A study along a trekking corridor in the Sikkim Himalayas. Mountain Res Dev 25 (3): 235-243.

Chettri N. 2010. Cross-taxon congruence in a trekking corridor of Sikkim Himalayas: surrogate analysis for conservation planning. J Nature Conserv 18: 75-88.

CITES. 2018. Checklist of CITES Species. http: //checklist.cites.org/\#/en./ [7 May 2018].

Colwell RK. 2014. Estimate S (version 9.1.0). Available at: http;//purl.oclc.org/estimates/ Accessed on 15 April 2015.

Dahal BR, McAlpine CA, Maron M. 2015. Impacts of extractive forest uses on bird assemblages vary with landscape context in lowland Nepal. Biol Conserv 186: 167-175.

Das S, Roy S, Mukhopadhyay A. 2010. Diversity of arthropod natural enemies in the tea plantations of North Bengal with emphasis on their association with tea pests. Curr Sci 99 (10): 1457-1463.

Datta TK. 2010. Darjeeling Tea in India. In: Lecoent A, Vandecandelaere E, Cadilhol JJ (eds.) Quality linked to the geographical origin and geographical indications: lessons learned from six case studies in Asia, RAP Publication 2010/04. Food and Agriculture Organization of the United Nations Regional Office for Asia and the Pacific, Bangkok.

Elsen PR, Kalyanaraman R, Ramesh K, Wilcove DS. 2016. The importance of agricultural lands for Himalayan birds in winter. Conserv Biol 31 (2): 416-426.

Flohre A, Fischer C, Aavik T, Bengtsson J, Berendse F, Bommarco R, Ceryngier P, Clement LW, Dennis C, Eggers S, Emmerson M, Geiger F, Guerrero I, Hawro V, Inchausti P, Liira J, Morales MB, Onate JJ, Part T, Weisser WW, Winquist C, Thies C, Tscharntke T. 2011. Agricultural intensification and biodiversity partitioning in European landscapes comparing plants, carabids and birds. Ecol Appl 21 (5): 1772-1781.

Greenberg R. 1981. The abundance and seasonality of forest canopy birds on Barro Colorado Island, Panama. Biotropica 13 (4): 241-251.

Grimmett R, Inskipp C, Inskipp T. 2011. Birds of the Indian Subcontinent. Helm field Guides, Second Edition, Oxford University Press.

Harvey CA, Villalobos JAG. 2007. Agroforestry systems conserve species-rich but modified assemblages of tropical birds and bats. Biodiv Conserv 16 (8): 2257-2292.

Hazarika LK, Bhuyan M, Hazarika BN. 2009. Insect pest of tea and their management. Ann Rev Entomol 54: 267-284.

Kottawa-Arachchi JD, Gamage RN. 2015. Avifaunal diversity and bird community responses to man-made habitats in St. Coombs Tea Estate, Sri Lanka. J Threat Taxa 7 (2): 6878-6890.

Laurance WF, Sayer J, Cassman KG. 2014. Agricultural expansion and its impacts on tropical nature. Trends Ecol Evol 29 (2): 107-116. 
Lin N, Nam TT, Perera J. 2012. Response of birds to different management types of tea cultivation in a forest-agriculture landscape. In: Harrison R, Shi LL, Liu JX (eds.) Proceedings of the Advanced Field Course in Ecology and Conservation-XTBG 2012.

MacArthur RH, Recher H, Cody ML. 1966. On the relation between habitat selection and species diversity. Amer Nat 100: 319-332.

Mastrangelo ME, Gavin MC. 2014. Impacts of agriculture intensification on avian richness at multiple scales in Dry Chaco forests. Biol Conserv 179: 63-71.

Mayfield MM, Boni, MF, Daily GC, Ackerly D. 2005. Species and functional diversity of native and human-dominated plant communities. Ecology 86 (9): 2365-2372.

McNeely JA, Schroth G. 2006. Agroforestry and biodiversity conservation-Traditional practices, present dynamics and lessons for the future. Biodiv Conserv 15 (2): 549-554.

Mellink E, Riojas-López ME, Cárdenas-García M. 2017. Biodiversity conservation in an anthropized landscape: Trees, not patch size drive, bird community composition in a low-input agro-ecosystem. PLoS One 12 (7): e0179438. DOI: 10.1371/journal.pone.0179438

Pimentel D, Stachow U, Takacs DA, Brubaker HW, Dumas AR, Meaney JJ, O'Niel JAS, Onsi DE, Corxilius DB. 1992. Conserving biologica diversity, agricultural/forestry systems: most biological diversity exists in human-managed ecosystems. Bioscience 42 (5): 354-362.

Praveen J, Jayapal R, Pittie A. 2018. Checklist of the birds of India (v2.1). http://www.indianbirds.in/india/ Accessed on 7 May 2018.

Sharma LN, Vetaas OR. 2015. Does agro-forestry conserve trees? A comparison of tree species diversity between farmland and forest in mid-hills of central Himalaya. Biodiv Conserv 24 (8): 2047-2061.
Sharma R, Xu J, Sharma G. 2007. Traditional agroforestry in the Eastern Himalayan region: Land management system supporting ecosystem services. Trop Ecol 48 (2): 189-200.

Sinu PA. 2011. Avian pest control in tea plantations of sub-Himalayan plains of Northeast India: Mixed-species foraging flock matters. Biol Control 58 (3): 362-366.

Soh MCK, Sodhi NS, Lim SLH. 2006. High sensitivity of montane bird communities to habitat disturbance in Peninsular Malaysia. Biol Conserv 129 (2): 149-166.

Sreekar R, Mohan A, Das S, Agarwal P, Vivek R. 2013. Natural windbreaks sustain bird diversity in a tea-dominated landscape. PLoS One 8: e70379. DOI: 10.1371/journal.pone.0070379

Subasinghe K, Sumanapala AP. 2014. Biological and functional diversity of bird communities in natural and human modified habitats in Northern Flank of Knuckles Mountain Forest Range, Sri Lanka. Biodiversitas 15 (2): 200-205.

Thiollay JM. 1995. The role of traditional agroforests in the conservation of rain forest bird diversity in Sumatra. Conserv Biol 9 (2): 335-353.

Tscharntke T, Sekercioglu CH, Dietsch TV, Sodhi NS, Hoen P, Tylianakis JM. 2008. Landscape constraints on functional diversity of birds and insects in tropical agroecosystems. Ecology 89 (4): 944-951.

Uezu A, Beyer DD, Metzger JP. 2008. Can agroforest woodlots work as stepping stones for birds in the Atlantic forest region? Biodiv Conserv 17 (8): 1907-1922.

Vandermeer J, Perfecto I. 2007. The Agricultural matrix and a future paradigm for conservation. Conserv Biol 21 (1): 271-277.

Yashmita-Ulman, Sharma M, Kumar A. 2016. Agroforestry Systems as Habitat for Avian Species: Assessing its role in conservation. Proc Zool Soc. DOI: 10.1007/s12595-016-0198-3. 
Table S1. Bird species recorded during the present study in tea gardens of Kurseong Hill, Darjeeling, Eastern Himalaya, India

\begin{tabular}{|c|c|c|c|c|c|c|c|c|}
\hline \multirow{2}{*}{ Common name } & \multirow{2}{*}{ Scientific name } & \multirow{2}{*}{$\begin{array}{c}{ }^{1} \text { Feeding } \\
\text { guild }\end{array}$} & \multirow{2}{*}{$\begin{array}{c}{ }^{2} \text { Habitat } \\
\text { guild }\end{array}$} & \multicolumn{4}{|c|}{${ }^{3}$ Study sites } & \multirow{2}{*}{ Total } \\
\hline & & & & $\mathbf{A}$ & B & $\mathbf{C}$ & $\mathbf{D}$ & \\
\hline Olive-backed Pipit & Anthus hodgsoni & I & $\mathrm{OL}$ & 20 & 18 & 20 & 18 & 76 \\
\hline Red-vented Bulbul & Pycnonotus cafer & I & FG & 27 & 19 & 13 & 6 & 65 \\
\hline Grey Bushchat & Saxicola ferreus & I & FG & 8 & 29 & 7 & 16 & 60 \\
\hline Green-backed Tit & Parus monticolus & I & FG & 6 & 14 & 4 & 19 & 43 \\
\hline Aberrant Bush Warbler ${ }^{\#}$ & Horornis flavolivaceus & I & FS & 20 & 8 & 9 & 3 & 40 \\
\hline Blue Whistling Thrush & Myophonus caeruleus & I & FG & 7 & 12 & 2 & 7 & 28 \\
\hline Blue-fronted Redstart ${ }^{\#}$ & Phoenicurus frontalis & I & FG & 10 & 4 & 9 & 5 & 28 \\
\hline Ashy Drongo & Dicrurus leucophaeus & I & FS & 5 & & 5 & 12 & 22 \\
\hline Long-tailed Shrike ${ }^{\#}$ & Lanius schach & I & FG & 5 & 2 & 10 & 2 & 19 \\
\hline Great Barbet & Psilopogon virens & $\mathrm{F}$ & FS & 5 & 2 & 6 & 2 & 15 \\
\hline Barn Swallow"\# & Hirundo rustica & I & $\mathrm{OL}$ & 2 & & 10 & 2 & 14 \\
\hline Red-billed Leiothrix* & Leiothrix lutea & I & FG & & 5 & 7 & 1 & 13 \\
\hline Eurasian Tree Sparrow & Passer montanus & $\mathrm{G}$ & OL & & 11 & & & 11 \\
\hline Black Bulbul & Hypsipetes leucocephalus & I & FS & 6 & 0 & & 3 & 9 \\
\hline House Crow $\#$ & Corvus splendens & $\mathrm{O}$ & FG & & 3 & 2 & 3 & 8 \\
\hline Rufous-breasted Accentor ${ }^{\#}$ & Prunella strophiata & $\mathrm{I}$ & $\mathrm{OL}$ & & 8 & & & 8 \\
\hline Oriental Turtle Dove ${ }^{\#}$ & Streptopelia orientalis & G & FG & 3 & 2 & 1 & 1 & 7 \\
\hline White-browed Scimitar Babbler & Pomatorhinus schisticeps & I & FG & & & 2 & 5 & 7 \\
\hline Chestnut-crowned Laughingthrush ${ }^{\#}$ & Trochalopteron erythrocephalum & I & FG & & & 3 & 3 & 6 \\
\hline Cinereous Tit & Parus cinereus & I & FG & 1 & & 5 & & 6 \\
\hline Green-tailed Sunbird & Aethopyga nipalensis & $\mathrm{N}$ & FG & 2 & 1 & 3 & & 6 \\
\hline Grey-crowned Warbler ${ }^{\#}$ & Seicercus tephrocephalus & I & FS & & 2 & 2 & 2 & 6 \\
\hline Grey Treepie & Dendrocitta formosae & I & FS & & & 2 & 4 & 6 \\
\hline Rusty-cheeked Scimitar Babbler ${ }^{\#}$ & Erythrogenys erythrogenys & I & FG & 3 & 1 & & 2 & 6 \\
\hline Slaty-backed Forktail & Enicurus schistaceus & I & FG & 3 & & & 3 & 6 \\
\hline Verditer Flycatcher ${ }^{\#}$ & Eumyias thalassinus & I & FG & & & 2 & 4 & 6 \\
\hline Black-throated Tit & Aegithalos concinnus & I & FS & 5 & & & & 5 \\
\hline Common Kestrel* & Falco tinnunculus & $\mathrm{C}$ & FG & & & 3 & 2 & 5 \\
\hline Scarlet Minivet & Pericrocotus flammeus & $\mathrm{I}$ & FG & 3 & 2 & & & 5 \\
\hline Streaked Laughingthrush ${ }^{\#}$ & Trochalopteron lineatum & I & FG & & 5 & & & 5 \\
\hline White-capped Water Redstart & Phoenicurus leucocephalus & I & FG & 2 & & 3 & & 5 \\
\hline Chestnut-bellied Nuthatch & Sitta cinnamoventris & I & FG & 4 & & & & 4 \\
\hline Blue-throated Barbet & Psilopogon asiaticus & $\mathrm{F}$ & FS & & & 3 & & 3 \\
\hline Common Myna & Acridotheres tristis & $\mathrm{O}$ & $\mathrm{OL}$ & 3 & & & & 3 \\
\hline Siberian Stonechat ${ }^{\#}$ & Saxicola maurus & $\mathrm{I}$ & FG & 1 & & & 2 & 3 \\
\hline Red-tailed Minla & Minla ignotincta & I & FG & 3 & & & & 3 \\
\hline Rufous-necked Laughingthrush & Garrulax ruficollis & I & FG & & & 3 & & 3 \\
\hline Himalayan Bulbul & Pycnonotus leucogenis & I & FG & 1 & & & 1 & 2 \\
\hline Large-billed Crow & Corvus macrorhynchos & $\mathrm{O}$ & FG & & 2 & & & 2 \\
\hline Spotted Dove ${ }^{\#}$ & Streptopelia chinensis & G & FG & 1 & & 1 & & 2 \\
\hline Whiskered Yuhina $^{\#}$ & Yuhina flavicollis & $\mathrm{I}$ & FG & & 2 & & & 2 \\
\hline White-throated Fantail & Rhipidura albicollis & $\mathrm{I}$ & FG & 1 & & & 1 & 2 \\
\hline Asian Barred Owlet*\# & Glaucidium cuculoides & $\mathrm{C}$ & FS & & & 1 & & 1 \\
\hline Common Green Magpie & Cissa chinensis & $\mathrm{O}$ & FS & 1 & & & & 1 \\
\hline Eurasian Sparrowhawk*\# & Accipiter nisus & $\mathrm{C}$ & FG & & & & 1 & 1 \\
\hline Hill Prinia ${ }^{\#}$ & Prinia superciliaris & $\mathrm{I}$ & FG & & & & 1 & 1 \\
\hline Himalayan Bush Robin $\#$ & Tarsiger rufilatus & I & FG & 1 & & & & 1 \\
\hline Rusty-flanked Treecreeper ${ }^{\#}$ & Certhia nipalensis & I & FG & & & 1 & & 1 \\
\hline Total & & & & 159 & 152 & 139 & 131 & 581 \\
\hline
\end{tabular}

Note:

${ }^{1}$ Feeding guild: Carnivore (C), Frugivore (F), Granivore (G), Nectarivore (N), Omnivore (O), Insectivore (I)

${ }^{2}$ Habitat specialization: Forest Specialist (FS), Forest Generalist (FG), Openland (OL)

${ }^{3}$ Study sites: Spring Side (A), Naya Busty (B), Singell (C), Naya Bazar (D). Numbers represents number of individuals recorded during the present study.

*Species listed in CITES Appendix II (CITES 2018). \#New record of bird species for Tea plantations of Kurseong Hill.

Bird taxonomy follows Praveen et al. (2018). 